\title{
Conference Report Tourism, Cultural Diversity and Sustainable Development: The Tourism Dialogue at the Barcelona Forum 2004
}

\author{
Ralf Buckley \\ International Centre for Ecotourism Research, Griffith University, \\ Southport, Australia
}

The Dialogue on Tourism, Cultural Diversity and Sustainable Development at the Barcelona Forum was a three-day international conference with a distinguished parade of star speakers and panellists.

The Barcelona Forum is a large-scale urban redevelopment project which is converting a low-value sewage treatment site into a 30 ha high-value coastal resort. The total budget is $€ 3$ billion, with a $40 / 60$ split between public and private funding. Major works such as wavebreak islands and deepwater harbours have been constructed, and from May-September 2004, the site hosts a 20-week international expo, the Universal Forum of the Cultures (2004), with an additional operating budget of $€ 327$ million. This is presumably intended as a marketing device. Site works include a signature triangular tradeshow building with a 3200-seat underground auditorium, which could easily become an upmarket retail precinct and car park; and a convention centre and hotel. These are hosting 41 back-to-back conferences known as Dialogues. The rest of the Forum site contains performances and exhibitions, notably a futuristic display of hydrogen-powered and hybrid petrol/electric car designs by Toyota.

The Tourism Dialogue took place from 14-16 July 2004. The programme was run by Professor Tomas Azcarate of the Institute for Responsible Tourism (2004) and Professor Luis Jimenez of the Universitad Complutense de Madrid, with an international Scientific Advisory Committee chaired by Professor Jafar Jafari from the University of Wisconsin. It had three components: a three-day plenary program of two parallel symposia; a set of one-day specialist panel debates; and several streams of contributed academic and technical papers and posters. The plenaries and panels were international, with speakers including princes and presidents, ministers and mayors, and global and European heads of organisations such as the World Tourism Organisation (WTO), World Travel and Tourism Council (WTTC), the World Conservation Union (IUCN), the Convention on Biological Diversity (CBD), the UN, UNESCO, the European Commission (EC), and the Club of Rome. Regions represented ranged from Catalunya to Canada, England to Easter Island, Greece to the Gambia, Hong Kong to Hawaii, Iraq to Indonesia, Morocco to Mexico, Senegal to Saudi Arabia, Tanzania to Zanzibar. 
The Dialogue was run in Spanish, Catalan, Portuguese, French and English, with simultaneous translation throughout the panels and plenaries. The contributed papers were largely in Catalan and (Castilian) Spanish. From an ecotourism perspective the most interesting plenary session was perhaps that on 'Tourism in a Living Planet' which addressed biodiversity, protected areas and ecotourism; but there were high-profile presentations throughout, including Jonathan Tourtellot of National Geographic, and David Bellamy of the Conservation Foundation, as well as the major international organisations listed above. The full plenary programme is available in English on IRT (2004).

From an ecotourism perspective the most interesting panel session was perhaps that on Sustainable Tourism and Natural Heritage, chaired by Eugenio Yunis of WTO. The panel was sponsored by Fundacion Santander Central Hispano (FSCH, 2004a), which had also run a similar but independent regional event earlier in the year (FSCH, 2004b). It was in two parts, on natural heritage and environmental management tools respectively. In the first half, Eugenio Yunis of WTO presented an overview of issues; Ralf Buckley (2005) reviewed current trends in nature, eco, adventure and rural tourism; Reinhard Klein of the EC discussed tourism politics in the European Union; and Jean-Claude Jacques of IUCN examined tourism in protected areas. In the second half, the panel heard from representatives of local government associations and consumer groups, Alain-Phillippe Feutre of the International Hotel and Restaurant Association, and Dr Wolf Iwand from the large tour operator Touristik Union International.

A draft communiqué (ITR, 2004) was circulated for comment. Copies of recent published guidelines by CBD (2004), and the new tourism destination sustainability scorecard by National Geographic (Tourtellot, 2004) were also available. Plenary and panel presentations, and perhaps also contributed papers, are planned for publication in due course.

In the meantime, the main outcome may perhaps be summarised as follows. Theoretical debates over sustainable tourism and natural heritage in Spanish, Portuguese, French and German speaking nations seem to be rather similar to those in the English-language literature; but policy approaches in the European Union, including the UK, seem to be rather different from those in the Americas or Australia. And whilst many EU websites are available at least partially in English, much of the academic literature is not. In tourism as in other sectors, therefore, lack of translation is a major barrier to information exchange; but one we need to overcome.

\section{Correspondence}

Any correspondence should be directed to Ralf Buckley, International Centre for Ecotourism Research, Griffith University, Parklands Drive, Southport, Qld 4215, Australia (R.Buckley@griffith.edu.au).

\section{References}

Buckley, R.C. (2005) Social trends and ecotourism: Adventure recreation and amenity migration. Journal of Ecotourism 4 (1), 56-61 (this volume).

Convention on Biological Diversity (2004) Guidelines on Biodiversity and Tourism Development. CBD Secretariat, Montreal. See also www.biodiv.org. 
Fundacion Santander Central Hispano (2004a) Patrimonio Natural, Biodiversity y Turismo Sostenible. Cuadernos de Sostenibilidad y Patrimonio Natural 5. FSCH, Madrid.

Fundacion Santander Central Hispano y Institute de Turismo Responsible (2004b) Taller Internacional: Sostenibilidad Turistica y Patrimonio Natural. See also www.biospherehotels.org.

Institute for Responsible Tourism (2004) Tourism, cultural diversity and sustainable development. See also www.biospherehotels.com/tourism2004.

Instituto de Turismo Responsible (2004) Desarrollo Turistico, Patrimonio Natural y Biodiversidad en Clave de Sostenibilidad: Propuesto de Documento Final, 01.07.04. ITR, Madrid.

Tourtellot J. (2004) Destination scorecard. National Geographic Traveler, March 2004, $60-67$.

Universal Forum of the Cultures (2004) Forum Barcelona: Cultural Profile. UFC, Barcelona, with UNESCO, Espana Administracion General del Estado, Generalitat de Catalunya y Ajuntament de Barcelona. 